\title{
Bacillus Thuringiensis Cry Proteins: The Status of Their Therapeutic Potential in Infectious Diseases
}

\author{
Gloria G Guerrero $\mathbf{M}^{*}$ \\ Universidad Autónoma de Zacatecas, Mexico
}

*Corresponding author: Gloria G Guerrero M, Unidad Academica de Ciencias Biologicas. Universidad Autonoma de Mexico. Av Preparatoria S/N. Col Agronomicas. Zacatecaas, Zac. Mexico. Phone: +52 4921564376. E-mail: gloriaguillermina@uaz.edu.mx; gloguerrero9@gmail.com

To Cite This Article: Gloria G Guerrero M. Bacillus Thuringiensis Cry Proteins: The Status of Their Therapeutic Potential in Infectious Diseases. Am J Biomed Sci \& Res. 2019 - 3(2). AJBSR.MS.ID.000652. DOI: 10.34297/AJBSR.2019.03.000652

Received: May 15, 2019 | Published: May 28, 2019

\section{Introduction}

Bacillus thuringiensis Cry proteins has been the subject of intense research in the last three decades. Cry proteins are highly specific towards different orders of insects $[1,2]$. Bt Cry proteins are a multigenic family. It can be distinguished two main families: Cyt (cytolitic) and Cry (Crystal) protein [1,2]. The protoxins or inmature proteins weights $130 \mathrm{kDa}$. To be active, protoxins should be processed by the $\mathrm{C}$-terminal region, producing the fragment toxic of 60-70 kDa. The three-dimensional structure of the Cry1Aa, Cry3A toxins has been elucidated [1,2]. In general Cry toxins are formed by three domains $[1,2]$. Domain I, formed by a bundle of alpha-seven helix, domain II or the binding domain formed by antiparallel beta-sheet and the domain III formed also by a sandwich of beta-pledged sheets $[3,4]$ By another hand, it has been described the immunogenic and adjuvants properties of the protoxin Cry1Ac $[5,6]$. The study has been extended to other members of the Cry family, like the protoxins Cry1Aa, Cry1 Ab, Cry3A as well as to the Cry1A a, Cry1Ab and Cry3A toxins [7].

We have learned from all the studies performed in vitro as well as in vivo that Cry proteins are as strong immunogens as cholera toxin produced by Vibrio cholerae and enterotoxins from Eshcerichia coli, to induce immune responses of antibodies (IgA in serum and mucosal fluids) and to cause several effects in the different cell populations $[8,9]$. Despite of this the mechanism of immunogenicity and adjuvanticity remains to be understood. Protective adjuvant properties studies have been performed in the mouse model as for example, Naegleria fowleri [10], Plasmodium falciparum [11], Murine cisticercosis [12] Brucella abortus [13] and in a recent paper by us, a co-administration with M. bovis Bacillus Calmette Güerin (BCG vaccine) elicted isotypes and IgG subclass Abs as well as type Th1 cytokines (IFN-g) and Th17 type cytokines (IL-17) [14]. Furthermore, Bt Cry proteins adjuvant properties could also involve other important innate immune interactions such a those that play a key role against intracelular pathogens such as $M$ tuberculosis oxide nitric synthase (iNOS,
NO production), pro-inflammatory cytokines, IL-6, IL1-beta, TNF-alpha, IL-23-IL17 autophagy pathways [Guerrero et al., 2019; Juárez et al., in preparation 2019].

Under these experimental settings in vivo as well as in vitro, Cry proteins represent a viable and safe alternative against mycobacteia of the MTB complex [14]. Despite this the mechanism of immunogenicity and adjuvanticity remains to be understood to further. explore their therapeutic potential in clinic (infectious, chronic diseases) in mammals. At this point, it is worthy to mention those studies that have addressed, whether or not these properties depend of an interaction with molecules like receptors. Thus, it has been shown that pCry1Ac binds to microvellosity of intestinal mouse epithelium [15] and it seems that monocytes elicited a higher expression of FcRn receptor after immunized with pCry1Ac [16], regionalization of pIgR [17]. Moreover, macrophage pCry1Ac induced activation involves interaction with HSP70 and ERK1/2 and p38 pathways [18]. Although there still some concerns regarding the toxicity of the Cry toxins $[19,20]$ we think that experimental settings should be carefully followed [21,22] and the status as an adjuvant for therapeutic issues remains promisorious, Furthermore, the immunobiology of the Bt Cry proteins in evolutive biology per se represent a challenging opportunity to gain insight about: What is the role of Bt Cry proteins in nature, in particularly in mammals?. Is the structural information playing a dual role to be functional in animal health including man?. The hypothesis is that Bt Cry proteins are a remarkable biological system designed to interact either with the insects as and with the host immune system. In the first case, is to species conservation (Bt spore germination), while in the second, to function as an mucosal adjuvant for example i.e. in chronic infectious diseases (bacterial, viral).

\section{Acknowledgement}

The author is grateful with SNI-CONACYT and PERFIL PRODEP for financial support. 


\section{References}

1. De Maagd RA, Bravo A, N Crickmore (2001) How Bacillus thuringiensis has evolved specific toxins to colonize the insect world. Trends Genet 17(4): 193-199.

2. López PL, Soberón M, Bravo A (2013) Bacillus thuringiensis insecticidal thee-domain Cry toxins: mode of action, insect resistance and consequences for crop protection. FEMS Microbiol Rev 37(1): 3-22.

3. Li J, Carroll J, DJ Ellar (1991) Crystal structure of insecticidal deltaendotoxin from Bacillus thuringiensis at $2.5 \AA$ resolution. Nature 353(6347): 815-821.

4. Grochuslki PL, Masson S, Borisova M, Pusztai Carey JI, Schwartz R, et al. (1995) Bacillus thuringiensis Cry1A(a) toxin: insecticidal crystal structure and channel formation. J Mol Biol 254(3): 447-464.

5. Vázquez Padrón RI, Moreno Fierros L, Neri Bazán L, de la Riva GA, López Revilla (1999) Intragastric and intraperitoneal administration of Cry1Ac protoxin from Bacillus thuringiensis induces systemic and mucosal antibody responses in mice. Life Science 64(21): 1897-1912.

6. Moreno Fierros L, García N, Gutiérrez R, López-Revilla R, Vázquez-Padrón RI (2000) Intranasal, rectal and intraperitoneal immunization with protoxin Cry1Ac from Bacillus thuringiensis induces compartmentalized serum, intestinal, vaginal and pulmonary immune responses in BALB/c mice. Microbes Infect 2(8): 885-890

7. Guerrero GG, Dean DH, Moreno Fierros L (2004) Structural Implication of the induced immune response by Bacillus thuringiensis Cry proteins: role of the N-terminal region. Mol Immunol 41(12): 1177-1183.

8. Jee Boong L, JI Eun J, Man Ki S, Chang J (2009) Intranasal delivery of cholera toxin induces TH17-dominated T-Cell response to bystander antigens. PLOSONE 4: e5190.

9. Datta SK, Sabet M, Nguyen KPL, Valdéz, PA, González-Navajas JM, et al. (2010) Mucosal adjuvant activity of cholera toxin requires Th17 cells and protects against inhalation anthrax. PNAs. 107(23): 10638-10643.

10. Rojas Hernández S, Rodriguez Monroy MA, López Revilla R, Reséndiz Albor AA, Moreno Fierros L (2004) Intranasal coadministration of the Cry1Ac protoxin with amoebal lysates increases protection against Naegleria fowleri meningoencephalitis. Infect Immun 72(8): 4368-4375.

11. Moreno Fierros L, García Hernández AL, Ilhuicatzi Alvarado D, Rivera Santiago L, Torres Martínez M, et al. (2013) The protoxin Cry1Ac of Bacillus thuringiensis improves the protection conferred by intranasal immunization with Brucella abortus RB51 in a mouse model. Int Immunopharmacol 17: 1051-1066.

12. Ibarra Moreno S, García Hernández AL, Moreno Fierros L (2014) Coadministration of protoxin Cry1Ac from Bacillus thuringiensis with metacestode extract confers protective immunity to murine cysticercosis. Parasite Immunol 36(6): 266-270.

13. González González E, García HernándezAL, Flores Mejía R, López Santiago R, Moreno Fierros L (2016) The protoxin Cry1Ac of Bacillus thuringiensis improves the protection conferred by intranasal immunization with Brucella abortus RB51 in a mouse model. Vet Microbiol 175(2-4): 382328.

14. Favela Hernandez JM, Balderas RI, Guerrero GG (2018) The potential of a commercial product based on Bacillus thuringiensis Cry $1 \mathrm{~A}$ as a immunogen and adjuvant. Madridge Journal of Immunology 2: 58-64.

15. Vázquez Padrón RI, González Cabrera J, García TC, Neri Bazán L, Hernández M, MorenoFierros L, et al. (2000) Cry1Ac protoxin from Bacillus thuringiensis sp kurstaki HD 73 binds to surface proteins in the mouse small intestine. Biochem Biophys Res Commun 271(1): 54-58.

16. Verdin Teran SL,Vilches Flores A, L Moreno Fierros (2009) Immunization with Cry1Ac from Bacillus thuringiensis Increases Intestinal IgG Response and Induces the Expression of FcRn in the Intestinal Epithelium of Adult Mice. Scandinavian Journal of Immunology 70(6): 596-607.

17. Reséndiz Albor AA, Reina Garfias H, Rojas Hernández S, Jarillo Luna A, Rivera Aguilar V, et al. (2010) Regionalization of pIgR expression in the mucosa of mouse small intestine. Immunol Lett 128(1): 59-67.
18. Rubio Infante N, Ilhuicatzi Alvarado D, Torres Martínez M, Reyes Grajeda JP, Nava Acosta R, et al. (2018) The Macrophage Activation Induced by Bacillus thuringiensis Cry1Ac Protoxin Involves ERK1/2 and p38 Pathways and the Interaction with Cell-Surface-HSP70. J Cell Biochem 119(1): 580-598

19. Poletto MB, Miranda Vilela AL, Kuppe GC (2015) Toxicological evaluation of a potential immuosensitizer for use as a Mucosal Adjuvant Bacillus thuringiensis Cry1Ac spore-crystals: A possible inverse agonist that deserves further investigation. Toxins 7(12): 5348-5358.

20. Rubio Infante N, Moreno Fierros L (2016) An overview of the safety and biological effects of Bacillus thuringiensis Cry toxins in mammals. J Appl Toxicol 36(5): 630-648.

21. Shimada N, Miyamoto K, Kanda K, Murata H (2006) Bacillus thuringiensis insecticidal Cry1ab toxin does not affect the membrane integrity of the mammalian intestinal epithelial cells: An in vitro study. In Vitro Cell Dev Biol Anim 42(1-2): 45-49.

22. Adel Patient K, Guimaraes VD, Paris A, Drumare MF, Ah Leung S, et al. (2011) Immunological and Metabolomic impacts of Administration of Cry1Ab protein and MON 810 Maize in mouse. PLOSONE 6(1): e16346. 